\title{
Seroprevalence of Paratuberculosis in Cattle in Ardahan Region
}

\author{
Mesut KARATAY', Enes AKYÜZ*1, Gürbüz GÖKCE1 \\ ${ }^{1}$ Kafkeas University, Faculty of Veterinary Medicine, Department of Internal Medicine, Kars, Turkey
}

\begin{abstract}
In this study, it was aimed to determine the prevalence of paratuberculosis the dairy cattle of Ardahan province. 11 focuses randomly selected from the Ardahan center and its districts and a total of 400 cattle blood sera from 22 farms in these centers constituted the study material. In the study, commercial ELISA antibody test kit was used to investigate "Mycobacterium avium subsp. Paratuberculosis" (MAP) antibodies in cattle blood serum samples. As a result of the analysis, 17 of 400 animals were positive for MAP and prevalence in Ardahan province and its vicinity was determined as $4.25 \%$ (17/400). Paratuberculosis was detected in 9 of 22 farms sampled. This result has been predicted that PTB is subclinical in dairy cattle in Ardahan region and may cause economic losses. Considering that this disease is zoonotic, it can be said that public health may also be affected. Therefore, it will be beneficial to carry out more studies on pTB.
\end{abstract}

Keywords: Cattle, Johne's Disease, Paratuberkulosis, Seroprevalence

Ardahan Yöresindeki Sığırlarda Paratüberküloz’un Seroprevalansı

ÖZ

Bu çalışmada Ardahan yöresindeki süt sığırlarında paratüberküloz’un (pTB) prevalansının belirlenmesi amaçlandı. Ardahan merkez ve ilçelerinden rastgele seçilen 11 odak ve bu odaklardaki 22 işletmeden alınan toplam 400 sığır kan serumu çalışmanın materyalini oluşturdu. Çalışmada, sığır kan serum örneklerinde "Mycobacterium avium subsp. Paratuberculosis" (MAP) antikorlarının araştırılması amacıyla ticari Enzyme Linked Immunosorbent Assay (ELISA) antikor test kiti kullanıldı. Analiz sonucunda 400 hayvandan 17'sinde MAP yönünden pozitiflik belirlendi. Ardahan ili ve çevresindeki yaygınlık oranı \%4,25 (17/400) olarak tespit edildi. Örnek alınan toplam 22 çiftliğin 9'unda paratüberküloz'un varlığı tespit edildi. Bu sonuçla, Ardahan yöresindeki süt sığırlarında pTB'un subklinik olarak bulunduğu ve ekonomik kayıplara yol açabileceği öngörülmüştür. Bu hastalığın zoonotik olduğu düşünüldüğünde halk sağlığının da etkilenebileceği söylenebilir. Bu nedenle pTB ile ilgili daha fazla çalışma yapilması faydalı olacaktır.

Anahtar Kelimeler: Johne's Hastalığı, Paratüberküloz, Seroprevalans, Sığır

To cite this article: Karatay M. Akyüz. E. Gökçe G. Seroprevalence of Paratuberculosis in Cattle in Ardahan Region. Kocatepe Vet J. (2020) 13(4): 327-331.

Submission: 22.05.2020 Accepted: 10.09.2020 Published Online: 05.11.2020

ORCID ID; MK: 0000-0001-7036-9100, EA: 0000-0002-3288-2058, GG: 0000-0002-2492-5193

*Corresponding author e-mail: enesakyuz_44@hotmail.com 


\section{GİRİŞ}

Paratüberküloz Norveç, İsveç ve Avustralya'daki bazı bölgeler hariç dünyanın birçok ülkesinde görülen yaygin bir hastalıktır. Paratüberkülozis ya da diğer ismi olan Johne's hastalı̆g "Mycobacterium avium subsp. paratuberculosis" (MAP)'in neden olduğu kronik, granülomatöz enteritis ile karakterize, hayvanların et ve süt veriminin azalmasının yanında, reprodüktif verimin önemli bir şekilde düşmesine ve büyük ekonomik kayıplara neden olan oldukça bulaşıcı bir enfeksiyondur (Gilardoni ve ark. 2012, Makav ve ark. 2013, Lingling Li ve ark. 2017, William ve ark. 2018). Etken ilk olarak Alman bilim adamlar1 Johne ve Frothingham tarafindan 1895 'de izole edilmiştir. Son yillarda yapilan fenotipik ve genotipik çalışmalar sonucunda tespit edilen etkenin Mycobacterium avium'a çok yakın olduğu ortaya konulduğundan ayrı bir tür olarak değil $M$. avium'un bir alt türü olması ve adının "Mycobacterium avium subspecies paratuberculosis" olmas1 gerektiği ileri sürülmüştür (Hurley ve ark. 1988, Thorel ve ark. 1990, Johne ve ark. 1895, Collins ve ark. 2003, Abendan ve ark. 2013). Hastalık 2-6 yaş ergin ineklerde kendini gösterir. Fakat etken buzağıların ilk aylarında hayvanları enfekte edebilir (Civelek 2018). Mycobacterium avium subsp. paratuberculosis'in konakç1 yaygınlı̆̆1 oldukça geniştir. Genellikle süt sığırlarında karşılaşılan bir etken olarak görülmektedir. Fakat deve, manda ve muflonlarda da paratüberküloz tespit edilmiştir. Aynı zamanda bazı hayvan türlerinde de (tavşan, ayı, tilki, rat, fare, yaban domuzu ve kuşlar) paratüberküloz tespit edilmiştir (Selbitz 2002, Machackova ve ark. 2004, Alvarez ve ark. 2005, Florou ve ark. 2005, Judge ve ark. 2005, Sivakumar ve ark. 2005). Hastalığın ortaya çıkışını hızlandıran hayvanın doğum yapması, nakiller, beslenme yetersizlikleri ve fazlalıkları, yüksek süt verimi, paraziter enfestasyonlar ve aynı zamanda ortaya çıkan başka hastalıklar, nemli ya da mineral bakımindan yetersiz meralarda otlatma gibi predispoze nedenlerdir (Baumgartner ve ark. 2006). Paratüberküloz'un teşhisinde, kesin bir tanı yöntemi bulunmamakla birlikte kan testleri, kültür ve mikroskobik muayene yöntemleri kullanılmaktadır. Rektum mukozası kazıntısı ve gaitadan alınan örneğin Ziehl-Neelsen tekniği ile boyanması, pTB basillerinin tespit edilmesinde en basit yöntemdir (Yazıcıoğlu 2011). Ayrıca ELISA subklinik enfekte hayvanların tespitinde, diğer testlere göre en güvenilir metot olduğu bildirilmiştir (Stricklands ve ark. 2005). ELISA, MAP'a karşı oluşan antikorların belirlenmesini sağlar. Günümüzde bu hastallğın tanısinda en yaygin kullanılan metottur (Kalis ve ark., 1999; Jubb ve ark., 2004; Yıldırım ve Civelek, 2013).

\section{MATERYAL VE METOT}

Bu çalışma, Kafkas Üniversitesi Hayvan Deneyleri Yerel Etik Kurul Başkanlığı'ndan alınan onay (KAÜHADYEK 2016-126) sonras1 yürütülmüştür. Sunulan çalışmada Ardahan ili merkezi ve ilçelerinden rastgele seçilen 11 odak belirlendi ve bu belirlenen odaklardan 22 issletmede bulunan klinik muayene sonucunda sağlıklı olan 2 yaş ve üzerinde toplam 400 sığır kan serumu çalışmanın materyalini oluşturdu. Vena coccygea'dan $10 \mathrm{~mL}$ antikoagulantsiz tüplere (Hemelab) kan örneği alındı. Kan örnekleri alındıktan sonra Kafkas Üniversitesi Veteriner Fakültesi İç Hastalıkları Anabilim Dalı laboratuvarında 3000 devirde 10 dakika santrifüj edildikten sonra elde edilen serum örnekleri mikrosantrifüj tüplerine konuldu ve etiketlenerek ölçüm yapilıncaya kadar $-20^{\circ} \mathrm{C}$ 'de muhafaza edildi. Çalışmada sığır kan serum örneklerinde MAP antikorlarının araştırılması amacıyla ticari ELISA antikor test kiti kullanıld1 (Mycobacterium paratuberculosis Antibody Test Kit, 06-07130-26, IDEXX). Serum örnekleri ve test kontrollerine ait değerler excel dosyasina aktarlarak, testin validitesi, ilgili hesaplamalar ve sonuçların yorumlanması üretici firmanın talimatları doğrultusunda gerçekleştirildi.

\section{İstatistiksel Değerlendirme}

ELISA sonuçlarına ait pozitif ve negatif veriler Microsoft Office Excel programı kullanilarak \% olarak hesaplandi.

\section{BULGULAR}

Analiz sonucunda 400 hayvandan 17'sinde MAP yönünden pozitiflik tespit edildi ve Ardahan ili ve çevresindeki yaygınlık oranı \%4,25 (17/400) olarak tespit edildi. Elde edilen sonuçlar Tablo 1'de verilmiştir.

Paratüberküloz açısından pozitif bulunan vakaların odak/köy ve işletmelere göre dağılımı Tablo 2'de sunulmuştur. Örnek alınan toplam 22 işletmenin 9'unda paratüberküloz varllğı tespit edildi. Paratüberküloz pozitif 17 vakanın ırk olarak dağılımı; 12 simental veya melezi ve 5 montofon veya melezi olarak tespit edildi (Tablo 3). Buna göre pozitif vakaların paratüberküloz oran1 simental veya melezlerinde \%70,58 (12/17), montofon veya melezlerinde \%29,42 (5/17) olarak gerçekleşti. Paratüberküloz pozitif vakaların yaşa göre dağılımı Tablo 4'te sunulmuştur. Pozitif 17 vakanın yaşa göre dağılımı; pozitif vakanın 12'si 2 yaşında veya 2 yaş ile 6 yaş arasında, 1'i 6 yaşında veya 6 ile 8 yaş arasında ve 4 'ü 8 yaşında veya 8 yaşından büyük olarak tespit edilmiştir. 
Tablo 1: Ardahan yöresinde paratüberküloz seroprevalansı.

Table 1: Paratuberculosis seroprevalence in Ardahan region.

\begin{tabular}{ccc}
\hline & Hayvan Sayıs & Yüzdesi (\%) \\
\hline Pozitif (+) & 17 & 4,25 \\
Negatif (-) & 383 & 95,75 \\
Toplam & 400 & 100 \\
\hline
\end{tabular}

Tablo 2: Seropozitif hayvanların işletmelere göre yaygınlık oranı.

Table 2: Prevalence rate of seropositive animals by enterprises.

\begin{tabular}{llll}
\hline Odak/Yerleşim & İşletme Kodu & Örnek Sayısı & Pozitif Örnek Sayısı \\
\hline \multirow{2}{*}{ Ardahan/Beşiktaş Köyü } & 1 & 29 & 0 \\
Göle/Sürügüden Köyü & 2 & 31 & 0 \\
& 10 & 25 & 5 \\
Göle/Yanatlı Köyü & 19 & 49 & 0 \\
Göle/Mollohasan Köyü & 11 & 40 & 0 \\
Göle/Tahtakıran Köyü & 9 & 7 & 1 \\
Göle/Okçu Köyü & 21 & 23 & 0 \\
Göle/Merkez & 22 & 12 & 0 \\
& 12 & 7 & 1 \\
Damal & 13 & 10 & 0 \\
& 14 & 15 & 4 \\
Posof/Çamyazı Köyü & 15 & 23 & 1 \\
& 17 & 18 & 0 \\
Çıldır/Göleben Köyü & 6 & 14 & 2 \\
& 8 & 12 & 1 \\
Çıldır/Gölebakan Köyü & 7 & 12 & 1 \\
Toplam & 5 & 19 & 1 \\
\hline
\end{tabular}

Tablo 3: Seropozitif hayvanların 1rklara göre dağılımı.

Table 3: Distribution of seropositive animals by race.

\begin{tabular}{llll}
\hline Irk & Hayvan sayıs1 & Pozitif Hayvan sayıs1 & $\begin{array}{l}\text { Pozitif Hayvan } \\
\text { Yüzdesi }\end{array}$ \\
\hline Simental veya melezi & 150 & 12 & $\% 70,58$ \\
Montofon veya melezi & 150 & 5 & $\% 29,42$ \\
Yerli irk veya melezi & 50 & 0 & 0 \\
Toplam & 400 & 17 & 100 \\
\hline
\end{tabular}

Tablo 4: Seropozitif hayvanların yaşa göre dağılımı.

Table 4: Distribution of seropositive animals by age.

\begin{tabular}{llll}
\hline Hayvanın yaşı & Hayvan sayıs & Pozitif hayvan sayısı & Pozitif Hayvan Yüzdesi \\
\hline$\geq \mathbf{2}-<\mathbf{6}$ & 252 & 12 & 70,59 \\
$\mathbf{2}-\mathbf{8}$ & 45 & 1 & 5,89 \\
$\geq \mathbf{8}$ & 103 & 4 & 23,52 \\
Toplam & 400 & 17 & 100 \\
\hline
\end{tabular}




\section{TARTIŞMA}

Dünyada paratüberküloz'un prevalansı ile ilgili çalışmalar mevcuttur. Bu durum dünyanın diğer yerlerinde de paratüberküloz'un önemli olduğu ve hala sorun oluşturduğunu göstermektedir. Genel olarak, Avrupa ülkelerindeki yaygınlı̆̆ının $\% 0$ ile \%19,8 arasında değiştiği belirlenmiştir (Nielsen ve ark. 2009). Ardahan yöresinde de prevalans oranı $(\% 4,25)$ bu aralı içerisindeydi. Paratüberküloz'un prevalansının, yapılan çalışmalara göre ülkeden ülkeye hatta kıtadan kitaya değişiklik gösterdiği saptanmıştır. $\mathrm{Bu}$ durum kullanılan tanı yöntemlerinin farklılığ1, ülkeden ülkeye göre yetiştirici bilincinin farklı̆̆1, yetiştirilen toprakların asit ve alkali farkı, bakım ve hijyen farklllıklarından kaynaklanabileceği düşünüldü. İç Anadolu'da yapılan bir çalışmada paratüberküloz'un seroprevalans1 $\% 2,7$ olarak saptanmıştır (Vural ve ark. 1988). Türkiye'de yapılan diğer çalışmalarda; Elazı̆̆ Bölgesinde \%3,4 ile \%5 (Çetinkaya ve ark. 2000) ve Uşak Bölgesinde \%2,5 ile \%20 (Yildırım ve ark. 2013) arasında değiştiği, ayrıca Trakya bölgesinde $\% 0$ (Ikız ve ark. 2005) ve Burdur Bölgesinde \%6,2 (Öztürk ve ark. 2010) olarak bulunmuştur. Makav ve ark. (2013), yaptıklar1 bir çalışmada paratüberküloz'un seroprevalansını Kars yöresinde ELISA yöntemiyle \%3,5 olarak bulmuşlardır. Sunulan bu çalışmada da Ardahan yöresinde ELISA yöntemiyle seroprevalans \%4,25 olarak bulundu. Sunulan çalışmadaki bu oran İç Anadolu, Elazığ ve Kars yöresinde yapılan çalışmalara yakın bulunmuştur. Paratüberküloz sığırlarda kronik ishal ve verim kayıplarına yol açan, MAP'ın neden olduğu bakteriyel bir hastalıktır. İşletme bazında önemli ekonomik kayıplara neden olmaktadır. Paratüberküloz'da kandaki antikor seviyesi hastalığın şiddeti ve yaşla artmaktadır. O nedenle 2 yaşın altındaki hayvanlarda güç teşhis edileceği bildirilmiştir (Whittington ve ark. 2001). Sunulan bu çalş̧mada da 2 yaşın üstündeki hayvanlarda kan örnekleri alınarak ELISA yöntemiyle MAP antikorları araştırılmıştır. Çünkü daha önceden yapılan çalışmalar da 2 yaşın altında seroprevalansın düşük olduğu 2 yașın üzerinde yüksek olduğu bildirilmiștir (Whittington ve ark. 2001, Sweeney ve ark. 2011). Yapılan bir çalışmada Burdur yöresinde hastalığın en yüksek yaygınlık oranını ise 3 yaşındaki sı̆̆ırlarda \%19,7 belirlemişlerdir (Öztürk ve ark. 2010). Kars yöresinde yapılan bir çalışmada Paratüberküloz'un en yüksek yaygınlık oranının yaşı 7 ve/veya 7 üzeri olarak gruplandırılan sığırlarda \%5,1 olduğu belirlenmiştir (Makav ve ark. 2013). Sunulan çalışmada ise paratüberküloz açısından 2-6 yaşları arasında sı̆̆ırlarda en yüksek oranda seropozitiflik $(\% 4,7)$ bulunmuştur. Bu yaş aralığında seropozitifliğin daha yüksek olmasının nedeni, numune alınan sığırların büyük çoğunluğunun 2-6 yaş aralığında olması, daha ilerki yaşlı numune sayısının az olması neticesinden kaynaklanabileceği düşünüldü. Sunulan çalışma ve belirtilen çalışmaların en yüksek seropozitiflik yaşı 2 ve üzerinde olmasıyla birbirleriyle benzerlik göstermiş, ayrıca litaratür bilgilerle uyumlu bulunmuştur (Whittington ve ark. 2001, Sweeney ve ark. 2011).

Burdur yöresinde pTB'nin prevalansı Holştayn ırkı sığırlarda \%6,2 olarak belirlenmiştir (Öztürk ve ark. 2010). Kars yöresinde yapılan bir çalışmada ise üç ayrı 1rkta yaygınlık oranları değerlendirildiğinde pozitif vakaların \%35,7'si simental ve melezi, \%50'si montofon ve melezi ve $\% 14,3$ 'ü yerli 1 rk ve melezi olarak tespit edildi (Makav ve ark. 2013). Bu çalışmada ise pozitif vakaların oranları simental ve simental melezlerinde $\% 70,58$ ve montofon veya melezlerinde \%29,42 oranında bulundu. Yerli ırklarda herhangi bir pozitifliğe rastlanmadi. Sunulan çalışmanın sonuçları ile yapılan çalışmaların kültür ırklarında oranın yüksek olmasıla benzerlik göstermiş̧ir. Bu durum kültür ırklarının hastalığa yerli ırklara göre daha duyarlı olabileceğini göstermektedir.

\section{SONUÇ}

Sonuç olarak Ardahan yöresindeki süt sığırlarında pTB nin seroprevalans1 \%4,25 olarak bulundu. Bu sonuç Ardahan yöresindeki sığırlarda p'TB'un subklinik olarak bulunduğunu ortaya koymaktadır. $\mathrm{Bu}$ durum hastalığa karşı ülkemizde olduğu gibi Ardahan yöresinde de bu hastalı̆̆a karşı kontrol önlemlerinin alınması gerektiğinin göstergesi olabilir. Sunulan bu çalışma da pTB hastalığının kültür ırkı sığırlarda daha yaygın olduğunu, dolayısıyla kültür ırklarının daha duyarlı olduğunu ortaya koymuştur. Ayrica bu hastaliğın zoonotik olduğu düşünüldüğünde halk sağlı̆̆ının da etkilenebileceği söylenebilir. Bu nedenle pTB ile ilgili daha fazla çalışma gerçekleştirilmesi fayda sağlayacaktır.

Çıkar Çatışması: Yazarlar, çıkar çatışması olmadığını beyan eder.

\section{KAYNAKLAR}

Abendan N, Sevilla IA, Prieto JM, Garrido JM, Juste RA, Alonso-Hearn M. Mycobacterium aviumsubspeciesparatuberculosis isolates from sheep and goats show reduced persistence in bovine macrophages than cattle,bison, deer and wild boar strains regardless of genotype. Vet Microbiol. 2013; 163:325-334.

Alvarez J, De Juan L, Aranaz A. A survey on paratuberculosis in wildlife in Spain. In:8th International Colloquium on Paratuberculosis. Copenhagen, Denmark, 2005.

Baumgartner W. ve Khol JL. Paratuberculosis (Johne'S Disease) in ruminants -an ongoing story, Slov Vet Res. 2006; 43(1):5-10.

Civelek T. Paratüberküloz 'sığırlarda paratüberküloz'. http://www.turancivelek.net/FileUpload/ks117047/File /ptb.pdf. Erişim tarihi: 14.02.2018.

Collins M. and Manning E. "Johne's Information Center" The University of Wisconsin-School of Veterinary Medicine, 13 March 2003. 
Çetinkaya B, Muz A, Ertaş HB, Öngör H, Sezen IYY, Gülcü HB. Süt ineklerinde paratüberküloz prevalansının polimeraz zincir reaksiyonu (PZR) ile saptanması. Turk J Vet Anim Sci. 2000; 24:371-379.

Florou M, Leontides L, Billinis C. Isolation of Mycobacteium avium subspecies paratuberculosis from non-ruminant wildlife in Greece. In: 8th International Colloquium on Paratuberculosis. Copenhagen, Denmark, 2005.

Gilardoni LR, Paolicchi FA, Mundo SL. Bovine paratuberculosis: a review of the advantages and disadvantages of different diagnostic tests. Rev Argent Microbiol. 2012; 44:201-215.

Hurley SS, Splitter GA. and Welch RA. Deoxyribonucleic acid relatedness of Mycobacterium paratuberculosis to other members of the family Mycobacteriaceae. Int. J. Syst. Bact. 1988; 38:143-146.

Ikiz S, Bagcigil AF, AK S, Ozgur NY, Loaz A. Paratuberculosis in cattle in Turkey detected by PZR. Medycyna Wet. 2005; 61:881-883.

Johne HA, Frothingham L. Ein eigenthumlicher fall von tuberculose beim rind (a particular case of tuberculosis in a cow). Deut Z Tiermed Vergl Pathol. 1895; 21:438-454.

Jubb TF, Sergeant ES, Callinan AP, Galvin J. Estimate of the sensitivity of an ELISA used to detect johne's disease in Victorian dairy cattle herds. Aust Vet J. 2004; 82: 569-73.

Judge J, Kyriazakis I, Greis A. Clustering of Mycobacterium avium subsp. paratuberculosis in rabbits and the environment: how hot is a hot spot? Appl Environ Microbiol. 2005; 71:6033-6038.

Kalis CHJ, Hesselink JW, Barkema HW. Comparison of culture of individual and strastegically pooled bovine faecal samples for Mycobacterium avium subsp. parastuberculosis. In: Manning, E.J.B., Collins, M.T. (Eds). Proceedings of the 6th International Colloquium on Paratuberculosis. Madison. Wisconsin. 1999; 344-8.

Lingling L, John PB, Joseph JC, Arlo R, Yrjo TG, Robab K, Megan S, Jessica RB, Vivek K. Identification of seroreactive antigens for the early diagnosis of Johne's disease in cattle. J. Pone. 2017; 9(1):1-18

Machackova M, Svastova P, Lamka J. Paratuberculosis in farmed and free-living wild ruminants in the Czech Republic. Vet Microbiol. 2004; 101:225-34.

Makav M. ve Gökçe E. Kars yöresi sı̆̆ırlarında subklinik paratuberkülozun seroprevalansi. Kafkas Univ Vet Fak Derg. 2013; 19(5):913-916.

Nielsen SS, Toft N. A review of prevalences of paratuberculosis in farmed animals in Europe. Prev. Vet. Med. 2009; 88:114.

Öztürk D, Pehlivanoğlu F, Tok AA, Günlü S, Güldalı Y, Turutoğlu H. Seroprevalence of paratuberculosis in the Burdur province (Turkey), in dairy cattle using the enzyme linked immunosorbent assay (ELISA). Israel J Vet Med, 2010; 65:53-57.

Selbitz HJ. Bakterielle Krankheiten der Tiere. In: Rolle M, Mayr A, eds. Medizinische Mikrobiologie, Infektions- und Seuchenlehre. 7. Aufl. Enke Verlag, pp 562-3, Stuttgart, 2002.
Sivakumar P, Tripathi BN, Singh N. Detection of Mycobacterium avium subsp. paratuberculosis in intestinal and lymph node tissues of water buffaloes (Bubalis bubalois) by PCR and bacterial culture. Vet Microbiol. 2005; 108:263-70.

Stricklands J, Scott HM., McJordan, ER. Effects of seasonal climatic conditions on the diagnosis of Mycobacterium avium subspecies paratuberculosis in dairy cattle. J Dairy Sci. 2005; 88: 2432-40.

Sweeney RW. Pathogenesis of paratuberculosis, In: Collins, T.M. (Eds) Johne's Disease. Vet. Clin. Food Anim. 2011; 27:525-535.

Thorel MF, Krichevski M and LevyFrebault VV. Numerical taxonomy of mycobactin-dependent mycobacteria, emended description of Mycobacterium avium, and description of Mycobactearium avium subsp. avium subsp. nov., Mycobacterium avium subsp. paratuberculosis subsp. nov and Mycobacterium avium subsp. silvaticum subsp. nov. Int. J. Syst. Bacteriol. 1990; 40:254-260.

Vural B, Atala N. Serological study on bovine paratuberculosis in central Anatolia using the microcomplement fixation and tube complement fixation tests. Etlik Vet. Mikrobiol Derg. 1988; 6:87-97.

Whittington RJ ve Sergeant ESG. Progress towards understanding the spread, detection and control of Mycobacterium avium subsp paratuberculosis in animal populations, Australian Veterinary Journal. 2001; 79:267278.

William CD and Kun TP. progress towards control of a mycobacterial pathogen, mycobacterium aviumsubsp. paratuberculosis, the causative agent of johne's disease in cattle and humans. Food Hyg. 2018; 33(4):221-228.

Yazıc1oğlu

Ö. Paratüberküloz, http://www.bornovavet.gov.tr/paratuberkuloz.htm. Erişim Tarihi: 03.05.2017.

Yıldırım D. Civelek T. Prevalence of subclinical paratuberculosis in dairy cattle in Uşak Region. Kafkas Univ Vet Fak Derg. 2013; 19(1):121-126. 